Volume 2, Nomor 1, Tahun 2020 Hal 354- 364

\title{
Sexuality in Education Begins in The Home (Pendidikan Seksual Berawal Dalam Keluarga)
}

\author{
Bernadetha Nadeak ${ }^{1}$, Elferida Sormin ${ }^{2}$, Lamhot Naibaho ${ }^{3}$, Evi Deliviana ${ }^{4}$ \\ 1,2,3,4 Universitas Kristen Indonesia, Jakarta, Indonesia \\ E-mail: bernadetha.nadeak@uki.ac.id; elferida.sormin@uki.ac.id; lamhot.naibaho@uki.ac.id; \\ evi.deliviana@uki.ac.id
}

\begin{abstract}
Abstrak
Pendidikan seksual di kalangan remaja menjadi salah satu prioritas pendidikan. Banyaknya kasus remaja yang tersangkut hukum terkait seksualitas sudah harus segera ditangani, bahkan diantisipasi lebih awal. Universitas Kristen Indonesia sebagai lembaga pendidikan yang juga turut merasakan tanggungjawab mengambil langkah konkrit melalui Pengabdian kepada Masyarakat dosen dalam melakukan edukasi dan sosialisasi tentang betapa pentingnya pendidikan tentang seksualitas di kalangan remaja. Kegiatan pengabdian kepada masyarakat ini dilakukan dengan melibatkan berbagai stake holder, di antaranya kalangan remaja (yang dalam hal ini diwakili oleh para siswa-siswi sekolah menengah pertama/SMP dan sekolah menengah umum/SMU), para orangtua siswa, para guru dan staf di sekolah Teruna Muda Scholl, JI Raya Ciangsana nomor 91, Ciangsana, Kec. Gunungputri, Kab. Bogor Prov. Jawa Barat. Hari pertama sosialisasi dan diskusi bersama dengan orangtua dengan topik "gaya komunikasi orangtua terhadap anak tentang seksual, adikksi pornografi di kalangan remaja dan bagaimana mengatasi adikksi pornografi bagi yang sudah terpapar melalui pendekatan psikologi", diskusi berlangsung sangat serius, di mana di antara para orangtua saling berbagi cerita dan berbagi informasi tentang apa yang menjadi kebiasaan anak-anak mereka di rumah dan bagaimana mereka melakukan penanganan terhadap anak yang menunjukkan gejala pemahaman yang salah akan seksual. Hari ke dua sosialisasi kepada para siswa dilaksanakan di aula sekolah dengan topik "pembekalan kesehatan reproduksi remaja dan bahaya addiksi pornografi di kalangan remaja"
\end{abstract}

Kata Kunci: seksual, pornografi, komunikasi, reproduksi

\begin{abstract}
Sexual education among adolescents is one of the priorities of education. Many cases of adolescents involved in law related to sexuality must be handled immediately, even anticipated earlier. Indonesian Christian University as an educational institution that also feels the responsibility of taking concrete steps through Community Service lecturers in conducting education and outreach about the importance of education about sexuality among adolescents. Community service activities are carried out by involving various stake holders, including young people (in this case represented by junior and senior high school students and senior high school students), parents of students, teachers and staff at school Teruna Muda Scholl, Jl Raya Ciangsana number 91, Ciangsana, Kec. Gunungputri, Kab. Bogor Prov. West Java. The first day of socialization and discussion with parents on the topic "parent's communication style towards children about sexual, pornographic addiction among adolescents and how to deal with pornographic addiction for those who have been exposed through psychological approaches", the discussion took place very seriously, where between parents each other sharing stories and sharing information about their children's habits at home and how they are handling children who show symptoms of a misunderstanding of sex. The second day of the socialization to students was held in the school hall with the topic "Provision of adolescent reproductive health and the dangers of addiction to pornography among teenagers
\end{abstract}

Keywords:. sexual, pornography, communication, reproduction 


\section{PENDAHULUAN}

Indonesia pada tahun 2030 diprediksi akan menjadi negara maju yang disampaikan oleh lembaga McKinsey Global Institute yang melakukan pengamatan terhadap GDP Indonesia yang berada di urutan ke 7 dunia, sehingga dengan alasan tersebut untuk jangka panjang on the right track Indonesia menuju negara maju. Namun dalam kenyataannya dalam jangka waktu pendek terdapa begitu banyak permasalahan yang dipandang dapat mempengaruhi pencapaian tersebut sehingga sulit terealisasikan.

Kualitas sumber daya manusia (SDM) menjadi hal yang paling utama dikhawatirkan dengan indeks pembangunan manusia (IPM) yang masih berada di kategori sedang. Selain kualitas ilmu pengetahuan, karakter para generasi muda yang menjadi harapan bangsa menjadi sesuatu hal yang sangat perlu dijaga dan dibangun ke arah yang positif guna memperoleh generasi muda dengan kapabilitas yang handal dan mampu bersaing di kancah internasional.
Hal utama yang menjadi ancaman bagi pengembangan potensi sumber daya manusia secara khusus para generasi muda selain narkoba adalah "pornografi". Data yang dirilis dari hasil penelitian ECPAT (End Child Prostitution, Child Pornography, and Trafficking of Children" menyebutkan bahwa tahun 2017 di enam kota di Indonesia terdapat 97 persen anak pada usia 14-18 tahun terpapar konten pornografi dan 40 persen di antaranya cenderung melakukan kekerasan seksual pada anak yang lainnya. (kpppa.go.id).

Pornografi berdampak buruk bagi perkembangan otak anak, dan sikap yang menunjukkan kecanduan terhadap pornografi merupakan salah satu dari beberapa perilaku menyimpang (Mulyadi, S. dalam mediaindonesia.com). Berbagai pemahaman muncul tentang pornografi, terlebih bagi kalangan remaja. Berdasarkan hasil penelitian Aryani, K. 2006 menyatakan bahwa sebagian besar informan yang menjadi sumber data penelitiannya menyatakan bahwa pornografi adalah sesuatu yang tidak bisa dihentikan dan tidak mungkin 
Volume 2, Nomor 1, Tahun 2020 Hal 354- 364 dilarang. Efek pornografi pada remaja diyakini meliputi empat tahapan yaitu, addiksi, eskalasi, desensitisasi dan act out (Supriati \& Fikawati dalam Rachmaniar, et all. 2018). Pada tahapan act out, seseorang akan cenderung menjadikan oranglain sebagai korban dengan alasan sudah menjadi korban sebelumnya, dengan kata lain kekerasan demi kekerasan menjadi satu rantai yang sulit untuk diputus, bahkan berujung kepada kehidupan selanjutnya ketika sudah berkeluarga, ada banyak korban kekerasan dalam rumah tangga yang pemicunya adalah permasalahan seksual, sebagaimana hasil penelitian Lase, F.J. 2018 yang menemukan bahwa terdapat empat karakteristik kekerasan seksual terhadap perempuan di Kabupaten Nias, yakni 1) Perkosaan, 2) Intimidasi Seksual , 3) Pemaksaan kehamilan untuk mendapatkan anak laki-laki dan 4) Pemaksanaan pemakaian alat kontrol reproduksi.

Dengan demikian bahaya dari kecanduan pornografi yang berujung kepada kekerasan seksual yang pada akhirnya menimbulkan dampak sosial lainnya secara langsung menjadi penyumbang tidak maksimalnya pencapaian pengembangan sumber daya manusia di Indonesia. Pemerintah, melalui beberapa program salah satunya melalui menkominfo sudah berusaha untuk melakukan pembatasan terhadap akses-akses yang mengandung konten pornografi. Metode penggunaan internet oleh kalangan remaja secara khusus perlu diawasi, jangan sampai fasilitas yang di awal diperuntukkan untuk menunjang pengembangan potensi dalam bidang ilmu pengetahuan dan teknologi akhirnya berujung pada penyalahgunaan fasilitas tersebut, sebagaimana hasil penelitian Qomariyah, A.N. 2009 yang menyatakan bahwa perilaku penggunaan internet pada kanagan remaja perkotaan, salah satu kecenderunggannya adalah untuk mengakses pornografi.

Selain upaya yang dilakukan oleh pemerintah, diperlukan keterlibatan semua stake holder dalam melakukan pencegahan, penanganan terhadap permasalahan ini. Terdapat beberapa langkah yang dapat dilakukan, salah satu di anataranya adalah pemberian pendidikan seksual secara dini kepada para kalangan remaja baik oleh orangtua maupun oleh lembaga pendidikan terkait. Beberapa Hasil penelitian menyatakan betapa 
Volume 2, Nomor 1, Tahun 2020 Hal 354- 364 pentingnya pendidikan seksual dilakukan terhadapa kalangan remaja, di antaranya Sugiasih, I. 2011 dinyatakan bahwa sebagian besar orangtua menyadari akan pentingnya pendidikan seksual untuk anak di usia dini. Orangtua adalah orang pertama yang harus melindungi anak-anaknya dari kekerasan, kejahatan dan pelecehan seksual (Azis, N.A. 2018). Hubungan kekeluargaan yang intim dan baik akan memberikan suasana yang baik pula bagi anak dalam satu keluarga, sehingga dengan adanya hubungan yang baik secara tidak langsung dapat menghindarkan sang anak dari pengaruh negatif yang timbul baik dari dalam maupun dari luar lingkungan. (Nadeak, B., et all. 2019). Pendidikan seksualitas melalui pendekatan agama juga dinilai sangat efektif sebagaimana hasil penelitian Towaf,S.M.,2008. Pakey, E.Y. 2016 tentang pendidikan seksualitas remaja dalam keluarga di Desa Katana Kecamatan Tobelo Timur Kabupaten Halmahera Utara. Andriani, Z.Z.D. 2018 tentang upaya pencegahan kekerasan seksual pada anak mellaui pendidikan kesehatan reproduksi sejak dini.

Berdasarkan hal-hal di atas, maka melalui kegiatan Pengabdian kepada
Masyarakat (PkM) yang merupakan salah satu dari tiga dharma perguruan tinggi, para dosen Universitas Kristen Indonesia melaksanakan Komunikasi, Informasi dan Edukasi (KIE) tentang pendidikan seksual bermula dalam keluarga "Sexuality in Education Begins in The Home" kepada para remaja yang dalam hal ini adalah siswa/siswi Sekolah Menengah Pertama (SMP) dan Sekolah Menengah Atas (SMA) dan juga kepada para orangtua siswa di Sekolah Teruna Muda School Jakarta.

\section{METODE}

Metode komunikasi, informasi dan edukasi yang dilakukan adalah melalui metode sosialisasi, sharing, diskusi dan konsultasi

\section{Sosialisasi}

Dalam tahapan sosialisasi para narasumber yang terdiri dari empat orang dosen dari displin ilmu yang berbeda (Kesehatan, pendidikan, psikologi dan bahasa) memberikan paparan tentang kondisi aktual kalangan remaja saat ini dari segi penegetahuan seksual dan bagaimana fakta tentang bahaya addiksi pornografi, selain itu juga dipaparkan bagaimana teknik komunikasi yang baik yang dapat dilakukan oleh 
Volume 2, Nomor 1, Tahun 2020 Hal 354- 364 orangtua supaya tercipta hubungan yang baik dalam keluarga.

\section{Sharing}

Dalam tahapan sharing, orangtua maupun siswa diberikan kesempatan untuk boleh terbuka dan menceritakan pengelaman masing-masing untuk selanjutnya dapat dijadikan bahan refleksi untuk yang lainnya

\section{Diskusi}

Untuk tahap diskusi, masing-masing peserta dengan bantuan moderator diperbolehkan memberikan pendapat atau masukan atau bahkan tanggapan terhadap apa yang sudah disharingkan oleh peserta yang lainnya

\section{Konsultasi}

Pada tahapan konsultasi ini, para narasumber memberikan waktu kepada para peserta yang ingin berkonsultasi baik secara langsung maupun tidak langsung terkait permasalah yang dihadapi.

Pelaksanaan kegiatan dilaksanakan secara bertahap selama dua hari, yang terbagi atas:

Hari I: Sosialisasi, sharing, diskusi, dan konsultasi dengan para orangtua

Hari II: Sosialisasi, sharing, diskusi dan konsultasi dengan para Siswa/i

Kegiatan Pengabdian kepada Masyarakat dilaksanakan pada bulan November 2019 bertempat di gedung serbaguna Sekolah Teruna Muda School, Jl Raya Ciangsana nomor 91, Ciangsana, Kec. Gunungputri, Kab. Bogor Prov. Jawa Barat dengan tema Sexuality in Education Begins in The Home (Pendidikan Seksual Berawal Dalam Keluarga). Adapun peserta dalam kegiatan pengabdian kepada masyarakat ini adalah para orangtua, guru dan juga siswa/i.

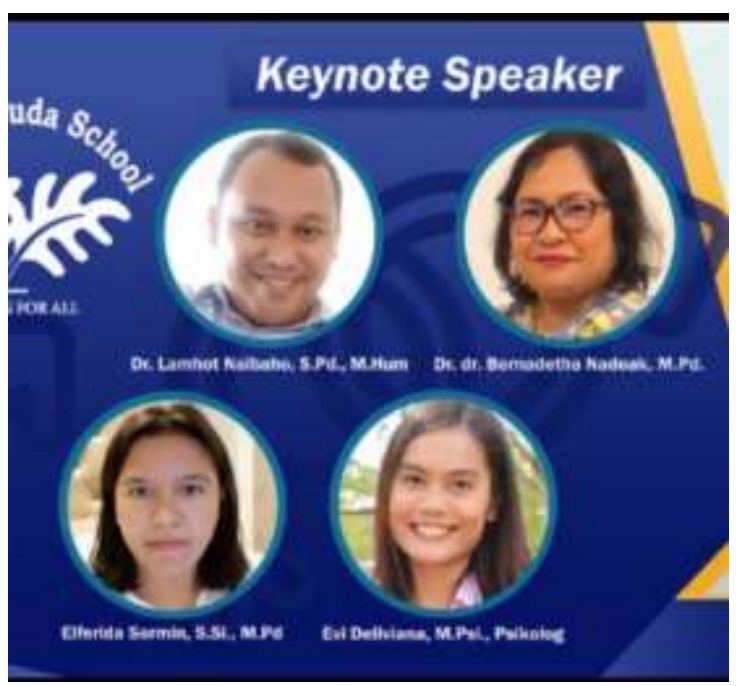

Gambar 1. Foto keempat narasumber dalam spanduk kegiatan

\section{Hari Pertama}

Peserta di hari pertama terdiri dari orangtua (ayah dan ibu) dari para siswa/i Teruna Muda School, sekitar 200 orang peserta mengikuti rangkaian kegiatan mulai dari sosialisasi oleh ke empat narasumber, di mana pada saat sosialisasi para narasumber secara 
Volume 2, Nomor 1, Tahun 2020 Hal 354- 364 paralel memaparkan materi terkait pendidikan seksual melalui pendekatan keilmuan yang berbeda-beda, di antaranya dari segi kesehatan, psikologi, pendidikan kimia dan bahasa.

Dalam paparan narasumber dijelaskan data real atau fakta tentang kondisi Indonesia terkait dengan maraknya kalangan remaja yang mengakses pornografi dan kejadian-kejadian kriminal yang terjadi terkait dengan permasalahan seksual di masyarakat yang pelakunya sebagian besar adalah kalangan remaja.Pada saat pemaparan ini sebagian orangtua sangat terkejut dengan data yang disajikan, karena menurut mereka hal itu sungguh di luar dugaan mereka.

Pada sesi sharing atau berbagi cerita, dengan dipandu oleh moderator para orangtua tidak sungkan dan tidak malu untuk berbagi cerita dan pengalaman mereka ketika hubungan mereka sebagai orangtua semakin renggang terhadap anak. Bahkan ada orangtua yang secara terang-terangan menceritakan keanehan yang terjadi pada anaknya yang suka menyendiri, jika ditanya langsung merespon dengan marah, selain itu dari hasil sharing diperoleh informasi bahwa ada anak yang sudah berani terang- terangan membawa pacar ke rumah ketika orangtua tidak ada di rumah.

Selanjutnya hasil sharing didiskusikan oleh peserta dan para narasumber. Semua peserta sangat antusias memberikan pendapat masing-masing. Dari beberapa hasil diskusi yang paling menarik adalah ketika ada orangtua yang memberikan solusi dengan menceritakan pengalaman pribadi bersama anak, di mana pada awalnya sang anak sudah menunjukkan tingkah yang sedikit aneh menurut orangtua, namun oleh orangtua tidak hentihentinya melakukan pendekatan dengan memposisikan diri orangtua layaknya teman atau sahabat si anak. Pada awalnya sulit, namun ketika si orangtua tidak pernah berhenti, akhirnya si anak perlahan-lahan semakin dekat dengan orangtua bahkan mau menceritakan apa saja yang dialami dan dirasakan oleh mereka. Hasil diskusi lainnya terdapat juga pendapat orangtua yang menceritakan bagaimana mereka mengutamakan kedisplinan kepada anak secara khusus dalam penggunaan gadget. Orangtua tersebut menceritakan bahwa dalam keluarga mereka diberlakukan sistem timing, di mana si anak hanya boleh menggunaka gadget di jam-jam 
Volume 2, Nomor 1, Tahun 2020 Hal 354- 364 tertentu dengan durasi waktu tertentu pula dan orangtua melakukan pengawasan terhadap konten yang diakses oleh anak. Selain itu, dari hasil diskusi, salah satu orangtua memberikan tips bagaimana supaya si anak terhindar dari pengaruh konten pornografi walaupun si anak tetap menggunakan gadget, yaitu dengan cara memasang sebuah aplikasi di gadget si anak yang fungsinya adalah untuk menutup akses yang mengandung konten pornografi, sehingga dengan demikian si anak tidak dapat masuk ke situs-situs yang isinya mengandung konten pornografi.

Kemudian oleh narasumber memberikan penjelasan bahwa semua langkah yang diceritakan oleh para orangtua memiliki tujuan yang sama yakni menghindarkan si anak dari bahaya paparan pornografi. Ketika berbicara tentang edukasi yang mengandung arti kata mendidik, di mana di dalamnya terdapat usaha menyampaikan sesuatu untuk kemudia dipahami dan dimiliki oleh seseorang yang dididik, maka dalam hal ini orangtua disarankan untuk pertama sekali mampu menjadi role model yang dapat dilihat secara nyata oleh si anak. Jangan sampai orangtua yang selalu melarang si anak mengakses situs pornografi, namun secara terangterangan pula menonton, mengakses atau bahkan melakukan hubungan suami-istri dengan tidak hati-hati, sehingga si anak secara tidak sengaja melihat kemudian mempraktikkan.

Selain menjadi role model, untuk tujuan supaya apa yang disampaikan dapat diterima dan dimiliki selanjutnya diamalkan oleh si anak, maka sebaiknya pendekatan secara personal perlu dilakukan. Hubungan yang terjalin dengan baik akan memudahkan seseorang untuk mempercayai apa yang disampaikan oleh seseorang yang lain.

Ketika acara sudah selesai, para narasumber masih tetap berada di tempat, memberi waktu bagi orangtua yang pada saat acara sharing dan diskusi merasa sungkan bertanya atau bercerita. Terdapat beberapa orangtua yang datang dan menceritakan dan mengkonsultasikan permasalahan mereka. Beberapa yang menjadi permasalahan utama adalah tidak adanya keharmonisan dalam rumahtangga menjadi salah satu pemicu si anak yang tadinya memiliki sikap yang baik, namun lamakelamaan menjadi berubah.

Hubungan yang harmonis antara ayah dan ibu sangatlah penting untuk 
Volume 2, Nomor 1, Tahun 2020 Hal 354- 364 disaksikan oleh anggota keluarga yang lain, tidak ada sikap saling menyalahkan antara ayah dan ibu, namun bersama-sama satu pendapat tentang sesuatu hal menyangkut si anak. Menyediakan waktu bersama, bercerita, bertukar pendapat dalam keluarga sangatlah penting. Orangtua tidak harus menyediakan biaya yang banyak, cukup menyediakan waktu secukupnya saja untuk dapat mendengar apa yang idrasakan oleh anggota keluarga yang lainnya atau bahkan juga ikut menceritakan apa yang dirasakan dengan tujuan agar semua anggota keluarga mempunyai rasa kepemilikan satu sama lain.

\section{Hari Kedua}

Peserta di hari kedua adalah siswa/i SMP dan SMA Teruna Muda School. Adapun sesi yang dilaksanakan sama dengan sesi bersama dengan orangtua di hari pertama yaitu sosialisasi, sharing, diskusi dan konsultasi.

Sosialisasi oleh keempat narasumber secara paralel memaparkan tentang bahaya seks bebas dan addiksi pornografi. Para siswa pada awalnya merasa tabu ketika membicarakan tentang seks di depan kelas, pada saat narasumber melakukan pemaparan dengan menunjukkan beberapa gambar seperti alat kelamin, dan lainnya, mereka langsung bersorak sambil menunjukkan raut wajah malu, bahkan ada yang menutup mata. Namun beberapa waktu kemudian ketika narasumber menyampaikan bahwa materi ini adalah ilmiah untuk

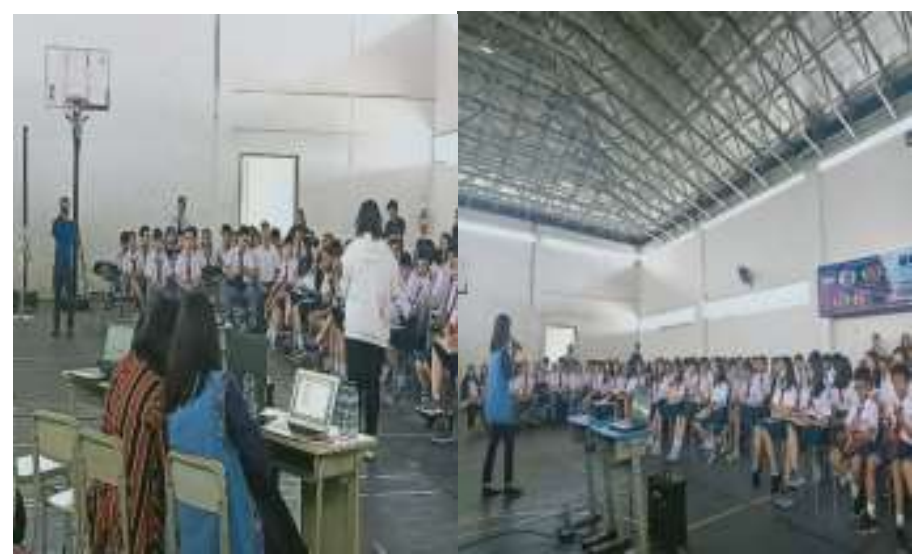

Gambar 2. Foto pada saat pemaparan oleh Narasumber

Pada saat sharing, Siswa SMA lebih mendominasi walaupun terdapat juga beberapa siswa SMP yang berani menceritakan pengalamannya. Dari beberapa sharing siswa, ada yang mengaku sudah berpacaran dan diketahui orangtua. Ada yang mengaku dalam berpacaran sudah pernah melakukan kissing.

Untuk mengantisipasi para peserta yang merasa sungkan dan malu untuk menyampaikan pertanyaan, maka oleh narasumber memberi kertas kepada para peserta untuk menuliskan pertanyaan secara tertulis tanpa menyebut nama. Dengan langkah ini 
Volume 2, Nomor 1, Tahun 2020 Hal 354- 364 para narasumber mendapatkan banyak pertanyaan yang dibahas dalam sesi diskusi. Beberapa dari pertanyaan tersebut ada yang mengaku sudah memiliki kebiasaan akses situs pornografi lalu bertanya apa yang harus dilakukan untuk mengubah kebiasaan tersebut dapat diubah.

Oleh para narasumber menyarankan pertama sekali untuk mendekatkan diri pada Tuhan, berdoa memohon kekuatan untuk bisa menjalankan keinginan untuk berubah. Kedua, melakukan kegiatan-kegiatan olah fisik atau olahraga yang dapat mengalihkan perhatian dari keinginan untuk akses pornografi. Ketiga, mendekatkan diri kepada keluarga dan jika sudah mampu boleh menceritakan perlahanlahan apa yang dirasakan kepada anggota keluarga lainnya. Keempat, bergabung dan bergaul dengan teman yang baik, yang suka melakukan halhal yang positif misalnya aktif di organisasi sekolah, agama dan lingkungan sosial lainnya.

Para peserta sangat antusias mengikuti sesi demi sesi. Mereka berpendapat seharusnya kalangan remaja tidak mudah terpancing dengan hal-hal negatif yang belum menjadi kebutuhan. Membina hubungan yang baik dengan keluarga menjadi sangat penting, karena merekalah yang berada paling dekat dengan kita.

Pada akhir acara, Teruna Muda School melalui kepala Sekolah menyampaikan ucapan terimakasih dan memberikan sertifikat penghargaan kepada para narasumber. Dikumentasi pada gambar 3.

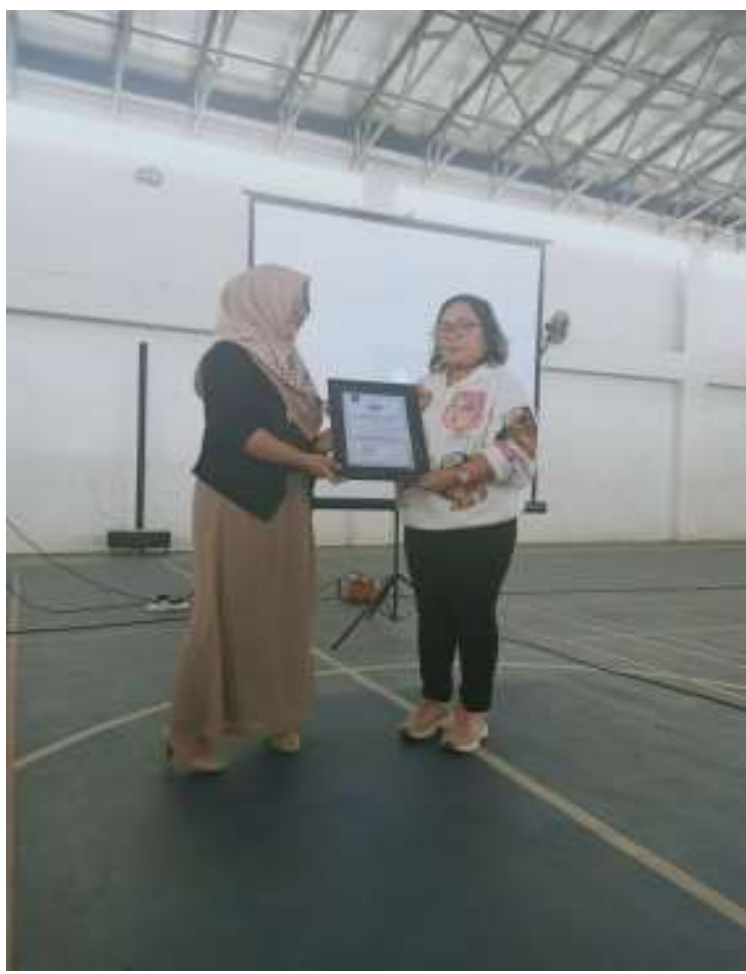

Gambar 3. Pemberian sertifikat oleh Kepala Sekolah Teruna Muda School kepada Narasumber

\section{KESIMPULAN}

Pendidikan seksual lebih dini yang dimulai yang dari rumah sangatlah penting dan harus dilakukan, peran orangtua menjadi yang paling utama sebagai role model, sehingga menimbulkan kepercayaan dalam diri si anak untuk setiap apa yang 
Volume 2, Nomor 1, Tahun 2020 Hal 354- 364 disampaikan dan diperintahkan oleh orangtua. Selain itu membina hubungan yang harmonis dalam keluarga menjadi kunci utama untuk dapat melakukan komunikasi yang baik dan akrab sehingga anggota keluarga tidak cenderung menyembunyikan apa yang dirasakan dan dialami.

\section{UCAPAN TERIMAKASIH}

Ucapan terimakasih kepada Teruna Muda School yang telah menjadi fasilitator dalam pelaksanaan kegiatan ini. Terimakasih juga kepada Universitas Kristen Indonesia yang telah menugaskan para dosen sebagai narasumber.

\section{REFERENSI}

Abidin, A. A., \& Luthfi, M. (2016). Urgensi Pendidikan Seks Pada Siswa Madrasah Ibtidaiyah Dalam Upaya Pencegahan Perilaku Penyimpangan Seksual Di Kabupaten Jombang. JURNAL ILMIAH DIDAKTIKA: Media IImiah Pendidikan dan Pengajaran, 17(1), 18-37.

Andriani, Z. Z. D., \& Nahdliyah, A. (2018). Upaya Pencegahan Kekerasan Seksual Pada Anak Melalui Pendidikan Kesehatan Reproduksi Sejak Dini.
LOYALITAS, Jurnal Pengabdian Kepada Masyarakat, 1(2), 126-148 Aryani, K. (2006). Analisis Penerimaan Remaja terhadap Wacana Pornografi dalam Situs-Situs Seks di Media Online. Jurnal Masyarakat Kebudayaan dan Politik. Tahun XIX. Nomor, 2.

Azis, N. A., Yuniarni, D., \& Lukmanulhakim, L. PEMAHAMAN ORANG TUA TERHADAP PENDIDIKAN SEKS ANAK USIA DINI DI KECAMATAN SEKADAU HILIR. Jurnal Pendidikan dan Pembelajaran Khatulistiwa, 9(3). Darmawan, A. J., \& Putri, D. G. (2014). Kampanye Online Anti Pornografi:“Pornografi” untuk Kalangan Anak Muda. Humaniora, 5(2), 624-633.

https://www.balitbangham.go.id/detailpost/ dampak-pornografi-dan-seks-bebasterhadap-prestasi-akademik https://mediaindonesia.com/read/detail/71 598-komnas-pa-sebut-97-remajaindonesia-pernah-akses-pornografi

https://kemenpppa.go.id/index.php/pag e/read/29/1966/cegah-anakterpapar-narkoba-dan-pornografisejak-dini

Lase, F. J. (2018). Karakteristik Kekerasan Seksual Terhadap Perempuan di Kabupaten Nias. 
Volume 2, Nomor 1, Tahun 2020 Hal 354- 364 Jurnal Inada: Kajian Perempuan Indonesia di Daerah Tertinggal, Terdepan, dan Terluar, 1(1), 1-25.

Nadeak, B., Deliviana, E., Sormin, E., Naibaho, L., \& Juwita, C. P. (2019).

PEMBINAAN

KETAHANAN

PERNIKAHAN

DAN

KEHARMONISAN KELUARGA

DENGAN TEMA "THE FAMILY RELATIONSHIP AND INTIMACY. JURNAL ComunitÃ Servizio: Jurnal Terkait Kegiatan Pengabdian kepada Masyarakat, terkhusus bidang Teknologi, Kewirausahaan dan Sosial Kemasyarakatan, 1(2), 179-185.

Pakey, E. Y. S. (2016). Pendidikan Seksualitas Remaja dalam Keluarga di Desa Katana Kecamatan Tobelo Timur Kabupaten Halmahera Utara. HOLISTIK, Journal Of Social and Culture.

Qomariyah, A. N. (2009). Perilaku penggunaan internet pada kalangan remaja di perkotaan. Universitas Airlangga Surabaya.

Rachmaniar, R., Prihandini, P., \& Janitra, P. A. (2018). Perilaku penggunaan smartphone dan akses pornografi di kalangan remaja perempuan. Jurnal Komunikasi Global, 7(1), 1-11.

Sugiasih, I. (2011). Need assessment mengenai pemberian pendidikan seksual yang dilakukan ibu untuk anak usia 3-5 tahun. Jurnal Psikologi Proyeksi, 6(1).

Towaf, S. M. (2008). Pendidikan Seksualitas dan Kesehatan Reproduksi Model Pesantren Bagi remaja. In Forum Kependidikan (Vol. 27, No. 2, pp. 146-159). 